\title{
Carbon-Negative Policies by Reusing Waste Wood as Material and Energy Resources for Mitigating Greenhouse Gas Emissions in Taiwan
}

\author{
Wen-Tien Tsai
}

Citation: Tsai, W.-T.

Carbon-Negative Policies by Reusing Waste Wood as Material and Energy Resources for Mitigating Greenhouse Gas Emissions in Taiwan. Atmosphere 2021, 12, 1220. https://doi.org/ 10.3390/atmos12091220

Academic Editors: Wan-Yu Liu and Alvaro Enríquez-de-Salamanca

Received: 9 August 2021

Accepted: 14 September 2021

Published: 17 September 2021

Publisher's Note: MDPI stays neutral with regard to jurisdictional claims in published maps and institutional affiliations.

Copyright: (C) 2021 by the author. Licensee MDPI, Basel, Switzerland. This article is an open access article distributed under the terms and conditions of the Creative Commons Attribution (CC BY) license (https:// creativecommons.org/licenses/by/ $4.0 /)$.
Graduate Institute of Bioresources, National Pingtung University of Science and Technology, Pingtung 912, Taiwan; wttsai@mail.npust.edu.tw; Tel.: +886-8-7703202

\begin{abstract}
Carbon-negative policies for mitigating the emissions of greenhouse gas (GHG) from the energy sector are becoming more urgent and important. Therefore, the environmental policies and regulatory promotion for reusing waste wood as a carbon-negative resource in Taiwan were discussed in this work, which focused on mitigating the emissions of GHG from the energy industries and the manufacturing and construction industries. Considering the official GHG inventory report, the trend analysis of GHG emissions from the energy and the manufacturing and construction industries was addressed first. In addition, this study placed emphasis on the environmental policies and regulatory measures for the material and energy resources from waste wood according to the promulgation of the relevant acts. It was found that the total GHG emissions from the energy and the manufacturing and construction industries accounted for over 80\% of net GHG emissions in 2018. In review of the resource recycling and circular economy, lignocellulose-based (or bamboo-based) char, ecological building material, and wood-to-biofuel pathways (e.g., solid recovered fuel) were discussed in this work because they have been promoted by the central competent authorities of the Council of Agriculture (COA), the Ministry of Interior (MOI), and the Environmental Protection Administration (EPA), respectively. In order to achieve the sustainable development goals (SDGs) in Taiwan, carbon-negative policies for reusing waste wood as material and energy resources will play an important role in the mitigation of GHG emissions.
\end{abstract}

Keywords: carbon-negative; waste wood reuse; greenhouse gas emission; environmental policy; regulatory measure

\section{Introduction}

It is well known that wood and its derived products can be considered carbon-neutral and carbon-negative materials due to the carbon sequestration process. Approximately one metric ton of carbon dioxide is sequestered for each cubic meter of wood via photosynthesis. Therefore, wood products can provide some energy and environmental benefits [1], including carbon storage extension, as well as clean fuel and green material use. When waste wood is generated and burned for energy or heat, the same amount of carbon is emitted without increasing atmospheric carbon. On the other hand, waste wood can be transformed into other wood-based materials such as biochar, activated carbon, and particleboard [2-5], further extending its lifetime in carbon storage. Obviously, wood products have many environmental advantages over non-wood materials, which are relevant to the mitigation of greenhouse gas (GHG) emissions or climate change [6]. Consequently, several countries, especially in the European Union (EU), have adopted the policies or directives for promoting electricity or heat from wood-based materials in recent years [7]. A study showed an increase in the consumption of wood fuel, chips, and pellets, as well as growth in the exports of wood pellets from North America and Russia (mainly for the European market) and Vietnam (for Korea and Japan) [8]. In addition, the adoption of circular-economy models for the 'cascading' use of wood makes it possible to prolong the 
storage of carbon in the wood-based products, thus delaying its release in the form of $\mathrm{CO}_{2}$ during its end-of-life energy recovery [9].

According to the World Resources Institute database [10], the energy sector, including transportation, electricity and heat, buildings, manufacturing and construction, fugitive emissions, and other fuel combustion [1], is by far the biggest source of anthropogenic GHG emissions, accounting for about three-quarters worldwide. In terms of the emission sources in the energy sector, the main contributors of GHG emissions (and their contributions) were determined in 2018 as follows [10]: heat and electricity (31.9\%), transportation (14.2\%), manufacturing and construction (12.6\%), residential buildings (11.4\%), and commercial buildings (6.8\%). On the other hand, the major GHG emission sources in the non-energy sector include livestock and manure (5.9\%), industrial processes $(4.5 \%)$, and agricultural soils (4.2\%) [10]. These figures suggest that the mitigation of GHG emissions from the energy sector should be a primary goal for addressing climate change [11]. In this regard, environmental policies and regulatory measures will play a crucial role in reducing the emissions of GHG and air pollutants from the energy sector [12], especially in subsectors such as heat and electricity, buildings, and agriculture.

Due to the natural forest ban policy in 1990 and the decreased income from domestic wood production, Taiwan's wood industry has declined. It was estimated that the percentages of domestic wood production and exported wood products in Taiwan are quite small $(<0.5 \%)$ [13]. Therefore, the total wood demand or consumption is close to its imported amount. According to the official data on the imported and exported amounts of wood [14], Figure 1 shows the variations during the period of 2003-2019, indicating a decreasing trend. The imported wood mostly came from Asian countries such as New Zealand, Malaysia, Japan, Myanmar, Papua New Guinea, Solomon Islands, and Vietnam. In this regard, the reuse of waste wood as an available precursor in the production of wood-based materials and biomass energy is becoming more important and urgent in Taiwan. Traditionally, waste wood is sent to a sanitary landfill, where another potent GHG (i.e., methane) is formed because of the anaerobic decomposition of lignocellulosic compositions. Since the carbon source of waste wood comes from the atmosphere and the sun, it can be considered as a biomass fuel or bioenergy source, thus releasing carbon but providing a substitution benefit as compared to fossil fuels. Furthermore, it can be transformed to other wood-based products such as biochar and building material. These "wood" products will continue to retain the atmospheric carbon in a lignocellulosic (sequestered) or elemental carbon form for their lifetime. Therefore, reusing waste wood as material and energy resources also provides a carbon-negative benefit based on a life-cycle assessment (LCA) [15-17].

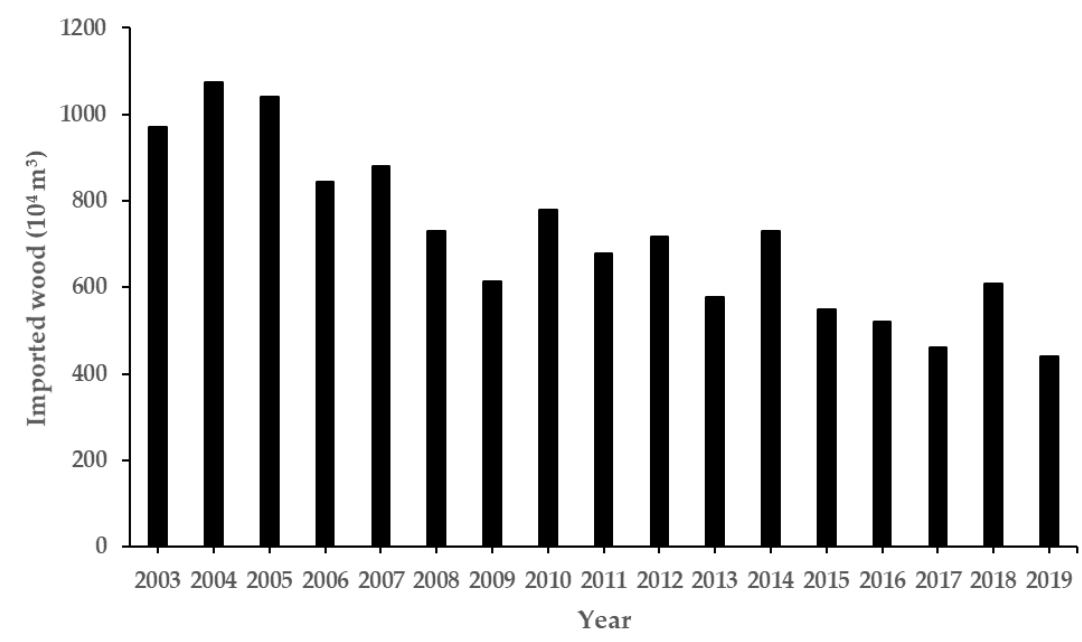

Figure 1. Imported amounts of wood in Taiwan since 2003 [14].

In review of the international trends in commodity materials and electricity (or heat) generation from biomass-based products [7-9], the Taiwan government adopted some 
carbon-negative measures to mitigate GHG emissions in recent years. More importantly, reusing waste wood as carbon-negative resources, including wood-to-biochar, wood-tobuilding material, and wood-to-energy pathways, has been less discussed in the academic literature. Therefore, this paper was aimed at addressing the following subjects:

- Trend analysis of GHG emissions from the energy and the manufacturing and construction industries.

- Environmental policies and regulatory measures for reusing waste wood as material and energy resources.

- Wood-based products for mitigating GHG emissions.

\section{Data Mining and Methodology}

In this work, the trend analysis of GHG emissions from the subsectors of the energy (heat and electricity) and the manufacturing and construction industries within the energy sector was based on the latest National Greenhouse Gas Inventory Report [18], which was issued by the Environmental Protection Administration (EPA) in Taiwan. In Taiwan, the report adopted the methodologies in accordance with the "2006 Intergovernmental Panel on Climate Change Guidelines for National Greenhouse Gas Inventories" proposed by the Intergovernmental Panel on Climate Change (IPCC) in 2006 [11]. In addition, the environmental policies and regulatory measures for reusing waste wood as material and energy resources were compiled from the official databases of the central competent authorities. Herein, the relevant acts for mitigating GHG emissions, including the Basic Environment Act, the Greenhouse Gas Reduction and Management Act, the Forestry Act, the Organic Agriculture Promotion Act, the Renewable Energy Development Act, the Energy Management Act, and the Building Act, were accessed from the website of the Ministry of Justice [19]. On the other hand, the important promotion measures, including renewable energy (e.g., wood fuels as biomass energy), low-carbon products (biochar products), and green building materials (e.g., wood-based materials), are further discussed in this study.

\section{Results and Discussion}

\subsection{Trend Analysis of GHG Emissions from the Energy and the Manufacturing and Construction Industries}

In Taiwan, the central competent authority (i.e., EPA) establishes the strategies to reduce and manage GHG emissions according to the Greenhouse Gas Reduction and Management Act passed in July 2015. Therefore, the EPA publishes the open-access report on "Greenhouse Gases Inventory" periodically [18]. Obviously, the energy-related GHG emissions comprise more than $90 \%$ of the total, where carbon dioxide $\left(\mathrm{CO}_{2}\right)$, methane $\left(\mathrm{CH}_{4}\right)$, and nitrous oxide $\left(\mathrm{N}_{2} \mathrm{O}\right)$ are responsible for the emissions due to fuel combustion for electricity and heat generation. Among the subsectors, the energy and the manufacturing and construction industries are the main emission sources in the energy sector with respect to the use of waste wood and wood materials as biomass fuels. This section summarizes the trend analysis of Taiwan's GHG emissions in the energy and the manufacturing and construction industries [18].

\subsubsection{Analysis of GHG Emissions from the Energy Industries}

According to the "Taiwan Greenhouse Gas Inventory Report" [18], total GHG emissions in the energy industries gradually increased from $166,211 \times 10^{3}$ metric tons of $\mathrm{CO}_{2 \mathrm{e}}$ in 2010 to $189,939 \times 10^{3}$ metric tons of $\mathrm{CO}_{2}$ equivalent $\left(\mathrm{CO}_{2 \mathrm{e}}\right)$ in 2018 , as shown in Figure 2 and Tables 1 and 2 [18]. It equivalently accounted for $64.05 \%$ of the total GHG emissions $\left(296,546 \times 10^{3}\right.$ metric tons of $\mathrm{CO}_{2 \mathrm{e}}$, not including the activities in the land-use, land-use change, and forestry sectors) in 2018, which was obviously higher than $58.07 \%$ in 2010 . An increase of $14.3 \%$ in GHG emissions was obtained at an average annual growth rate of $1.68 \%$. In comparison, $\mathrm{CO}_{2}$ accounted for about $99.3 \%$ of GHG emissions from the energy industries in Taiwan, followed by $\mathrm{N}_{2} \mathrm{O}$ and then $\mathrm{CH}_{4}$. As listed in Table 2, the most 
important GHG emission source in the energy industries came from electricity and heat production for the activities of the industrial, service, and residential sectors (Figure 3) [18], contributing about $90 \%$ to the total. In addition, the significant increase between 2015 and 2017 was mainly due to electricity production and petroleum refining expansion, which were the main sources of GHG emissions and electricity consumption in Taiwan [18]. This trend in GHG emissions was consistent with the average annual economic growth rate during this period of 2010-2018.

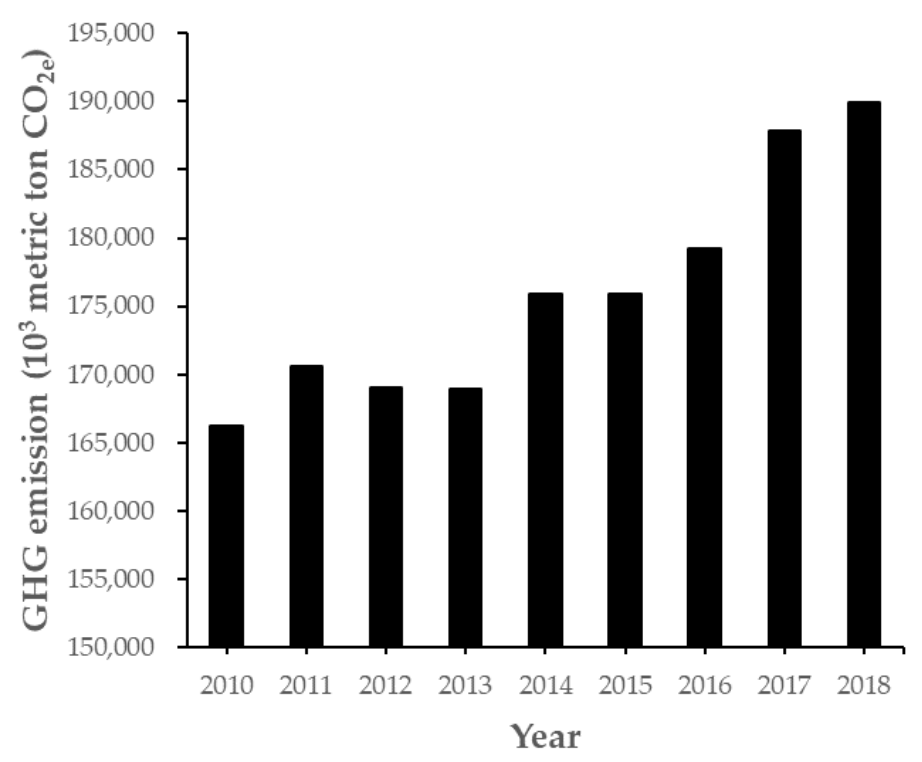

Figure 2. Variations in Taiwan's GHG emissions from the energy industries during the period of 2010-2018 [18].

Table 1. Taiwan's GHG emissions from the energy industries in terms of categories of GHG since $2010^{1}$.

\begin{tabular}{|c|c|c|c|c|c|c|c|c|c|}
\hline \multirow{2}{*}{ GHG Category } & \multicolumn{9}{|c|}{ Year } \\
\hline & 2010 & 2011 & 2012 & 2013 & 2014 & 2015 & 2016 & 2017 & 2018 \\
\hline Carbon dioxide $\left(\mathrm{CO}_{2}\right)$ & 165,522 & 169,884 & 168,333 & 168,271 & 175,180 & 175,198 & 178,569 & 187,135 & 189,212 \\
\hline Methane $\left(\mathrm{CH}_{4}\right)$ & 86 & 86 & 86 & 85 & 88 & 91 & 92 & 94 & 94 \\
\hline Nitrous oxide $\left(\mathrm{N}_{2} \mathrm{O}\right)$ & 603 & 607 & 603 & 595 & 599 & 585 & 595 & 621 & 633 \\
\hline Total emission & 166,211 & 170,577 & 169,022 & 168,951 & 175,867 & 175,874 & 179,256 & 187,850 & 189,939 \\
\hline
\end{tabular}

Table 2. Taiwan's GHG emissions from the energy industries in terms of GHG sources since $2010^{1}$.

\begin{tabular}{|c|c|c|c|c|c|c|c|c|c|}
\hline \multirow{2}{*}{ GHG Source } & \multicolumn{9}{|c|}{ Year } \\
\hline & 2010 & 2011 & 2012 & 2013 & 2014 & 2015 & 2016 & 2017 & 2018 \\
\hline $\begin{array}{l}\text { Main activity electricity } \\
\text { and heat production }\end{array}$ & 150,322 & 154,552 & 152,693 & 151,134 & 156,577 & 156,724 & 160,101 & 169,289 & 170,833 \\
\hline Petroleum refining & 7841 & 7171 & 7838 & 7553 & 8671 & 8710 & 8529 & 8314 & 8862 \\
\hline $\begin{array}{c}\text { Manufacture of solid fuels } \\
\text { and other energy } \\
\text { industries }\end{array}$ & 8048 & 8854 & 8491 & 10,264 & 10,621 & 10,437 & 10,626 & 10,247 & 10,244 \\
\hline Total emission & 166,211 & 170,577 & 169,022 & 168,951 & 175,867 & 175,874 & 179,256 & 187,850 & 189,939 \\
\hline
\end{tabular}




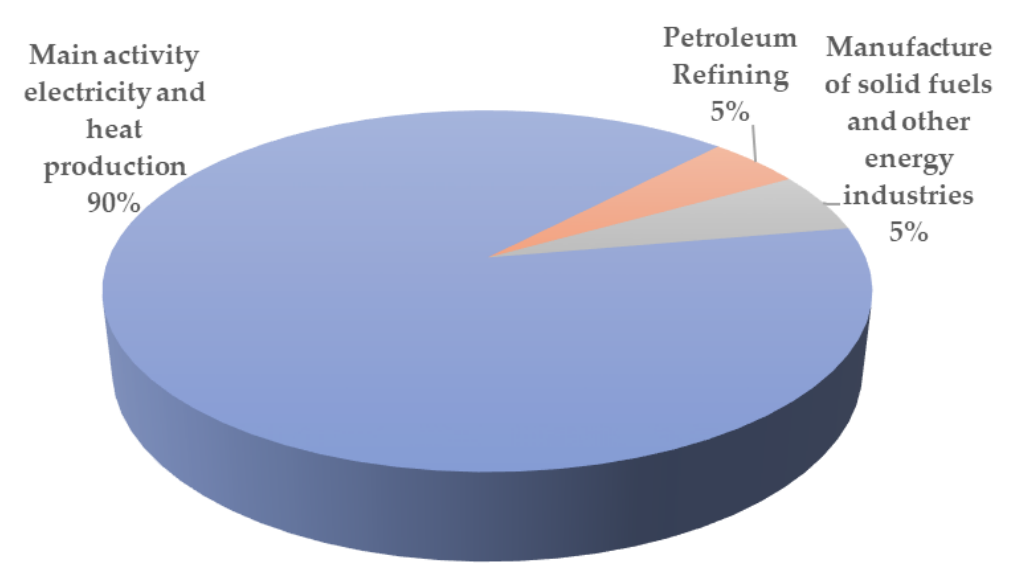

Figure 3. Pie chart of GHG emissions from the energy industries in terms of GHG sources in 2018 [18].

\subsubsection{Analysis of GHG Emissions from the Manufacturing and Construction Industries}

According to the report on the "2006 IPCC Guidelines for National Greenhouse Gas Inventories" [11], the subsector of the manufacturing and construction industries refers to the GHG emissions from fossil fuel combustion for the manufacturing and construction industries such as iron and steel, chemicals, minerals, machines, and electronics. Table 3 lists Taiwan's GHG emissions from the manufacturing and construction industries since 2010 [18]. Similarly, $\mathrm{CO}_{2}$ accounted for about $99.5 \%$ of GHG emissions from the manufacturing and construction industries in Taiwan, followed by $\mathrm{N}_{2} \mathrm{O}$ and then $\mathrm{CH}_{4}$. It should be noted that the GHG emissions from the manufacturing and construction industries indicated a decreasing trend at an average annual rate of $-2.93 \%$, as shown in Figure 4 [18]. This result can be attributed to the industrial structure change and the improvements in energy efficiency and energy conservation in the manufacturing and construction activities during this period. As also listed in Table 4 and depicted in Figure 5 [18], the main GHG emission sources in the manufacturing and construction industries were the activities related to chemical, iron and steel, and nonmetallic mineral (i.e., cement and cement products) manufacturing, contributing about $71-74 \%$ to the total. It is noteworthy that the percentages of GHG emissions from the nonmetallic mineral activities indicated a significant decrease during this period of 2010-2018, declining by about $31 \%$.

Table 3. Taiwan's GHG emissions from the manufacturing and construction industries in terms of categories of GHG since $2010{ }^{1}$.

\begin{tabular}{|c|c|c|c|c|c|c|c|c|c|}
\hline \multirow{2}{*}{ GHG Category } & \multicolumn{9}{|c|}{ Year } \\
\hline & 2010 & 2011 & 2012 & 2013 & 2014 & 2015 & 2016 & 2017 & 2018 \\
\hline Carbon dioxide $\left(\mathrm{CO}_{2}\right)$ & 41,360 & 42,298 & 41,000 & 42,019 & 38,953 & 38,074 & 38,296 & 36,741 & 33,401 \\
\hline Methane $\left(\mathrm{CH}_{4}\right)$ & 74 & 79 & 76 & 78 & 74 & 74 & 74 & 69 & 59 \\
\hline Nitrous oxide $\left(\mathrm{N}_{2} \mathrm{O}\right)$ & 135 & 144 & 137 & 140 & 133 & 131 & 131 & 123 & 103 \\
\hline Total emission & 41,569 & 42,521 & 41,213 & 42,237 & 39,160 & 38,279 & 38,501 & 36,933 & 33,563 \\
\hline
\end{tabular}

\footnotetext{
${ }^{1}$ Source [18]; unit: $10^{3}$ metric tons based on $\mathrm{CO}_{2}$ equivalent.
} 


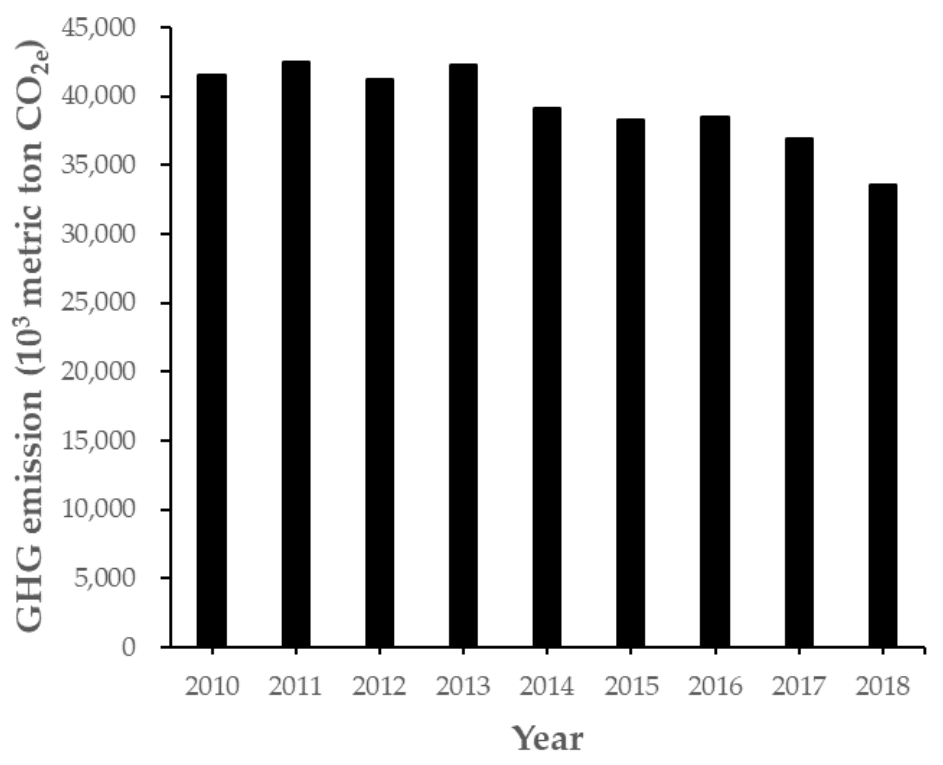

Figure 4. Variations in Taiwan's GHG emissions from the manufacturing and construction industries during the period of 2010-2018 [18].

Table 4. Taiwan's GHG emissions from the manufacturing and construction industries in terms of GHG sources since $2010^{1}$.

\begin{tabular}{|c|c|c|c|c|c|c|c|c|c|}
\hline \multirow{2}{*}{ GHG Source } & \multicolumn{9}{|c|}{ Year } \\
\hline & 2010 & 2011 & 2012 & 2013 & 2014 & 2015 & 2016 & 2017 & 2018 \\
\hline Iron and steel & 9546 & 9452 & 9472 & 10,447 & 8810 & 8661 & 8883 & 8557 & 8700 \\
\hline Non-ferrous metals & 296 & 300 & 278 & 287 & 294 & 276 & 259 & 219 & 290 \\
\hline Chemicals & 13,978 & 13,338 & 12,035 & 12,154 & 12,044 & 11,990 & 12,968 & 12,227 & 10,189 \\
\hline Pulp, paper, and print & 2175 & 2544 & 2627 & 2530 & 2397 & 2097 & 2044 & 1951 & 2285 \\
\hline $\begin{array}{l}\text { Food processing, } \\
\text { beverages, and tobacco }\end{array}$ & 1062 & 1057 & 1070 & 1005 & 1015 & 993 & 984 & 946 & 997 \\
\hline Nonmetallic minerals & 7222 & 8468 & 8114 & 8237 & 7016 & 6969 & 6428 & 5922 & 4993 \\
\hline Others & 7290 & 7362 & 7617 & 7577 & 7584 & 7293 & 6933 & 7111 & 6109 \\
\hline Total emission & 41,569 & 42,521 & 41,213 & 42,237 & 39,160 & 38,279 & 38,501 & 36,933 & 33,563 \\
\hline
\end{tabular}

${ }^{1}$ Source [18]; unit: $10^{3}$ metric tons based on $\mathrm{CO}_{2}$ equivalent.

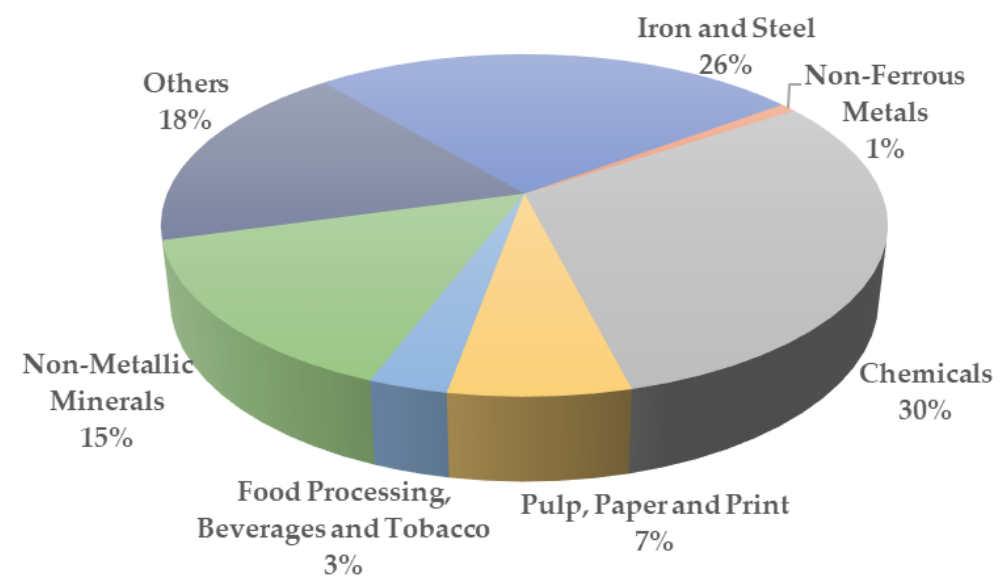

Figure 5. Pie chart of GHG emissions from the manufacturing and construction industries in terms of GHG sources in 2018 [18]. 


\subsection{Environmental Policies and Regulatory Measures Relevant to the Material and Energy Resources from Waste Wood}

In review of the carbon-negative benefits of reusing waste wood as material and energy resources, the central governing authorities in Taiwan jointly promulgated the environmental policies and regulatory measures under the authorizations of various acts or laws [19], which are addressed in this section.

\subsubsection{Environmental Protection Administration \\ Basic Environment Act}

In Taiwan, the Basic Environment Act is the foundation for all environmental policies. This law was passed on 11 December 2002, stipulating that economic and technological development should emphasize environmental protection for the purpose of long-term national welfare. In addition, any development must be sustainable in terms of future national security and quality of life. Concerning the reuse (or recycling) of waste, this Act requires the citizens, enterprises, and government entities at all levels to jointly share the duties and responsibilities for environmental protection, as described below.

- Government entities (policymakers)

Government entities at all levels should primarily incorporate environmental protection and sustainable development concepts. They should also develop related science and technology and establish economically efficient systems for environmental life-cycle management and green consumption to contend with issues related to the environment.

\section{- $\quad$ Enterprises (manufacturers)}

Enterprises should plan for the phasing in of environmental protection concepts when carrying out their manufacturing activities. According to the product life cycles and the purpose of achieving sustainable development, enterprises should promote clean production, prevent and reduce pollution, conserve resources, and recycle and reuse recycled resources and other raw materials or services that are beneficial to lessen their environmental impact.

\section{- $\quad$ Citizens (consumers)}

Citizens should uphold environmental protection concepts and lessen the environmental impact of daily life. In terms of consumer behaviors, citizens should, as a principle, practice green consumption. In terms of daily life, citizens should carry out waste reduction, separation, and reuse (or recycling).

\section{Greenhouse Gas Reduction and Management Act}

This Act was passed in July 2015, and it was aimed at mitigating GHG emissions at all levels of central and local governments by establishing adaptation strategies in Taiwan. Noticeably, the Act stipulated a mandatory reduction target of 50\% below 2005 GHG emission levels by 2050. In order to achieve the target and the sustainable development goals announced by the Taiwan government in July 2019 [20], the central competent authorities are expected to promote the following relevant GHG emission reduction and climate change adaptation actions:

- Development of renewable energy technology in the use of waste wood as an energy source.

- $\quad$ Reduction in and management of GHG emissions from buildings in the use of woodbased building materials.

- $\quad$ Reuse (or recycling) of waste wood as fuels or materials.

- $\quad$ Forest resource management in the forest's carbon sequestration. 


\subsubsection{Ministry of Economic Affairs}

Renewable Energy Development Act

In Taiwan, the Renewable Energy Development Act (REDA) is a legal foundation for promoting renewable energy and its industry development. The Act was recently revised on 1 May 2019. Among the regulatory measures for the promotion of biomass energy, the feed-in-tariff (FIT) and installation supports or subsidies may be the most important incentive in the establishment of a waste-to-power system. In addition, the central competent authority (i.e., Ministry of Economic Affairs, MOEA) may consider reasonable costs and profits for the heat utilization of biomass fuel, thus prescribing the regulations in the form of subsidies and rewards for heat utilization according to the effectiveness of their energy contribution. In order to produce biomass fuel, reward expenses for the exploitation of fallow land or idle land to plant energy crops can be financed by the special agriculture or energy fund. The regulation governing such reward eligibility, conditions, and subsidy methods, as well as their schedule, is prescribed by the MOEA in conjunction with the Council of Agriculture (COA).

\section{Energy Management Act}

With the aim of promoting the rational and efficient use of energy, the Taiwan government promulgated the Energy Management Act (EMA), which was recently revised in 2016. Thereafter, the goals of the EMA were to meet the national energy security goals and comply with the GGRMA passed in 2015. The energy user whose steam generation meets the level stipulated by the MOEA should install cogeneration or combined heat and power (CHP) systems in connection with the reuse of waste wood as a biomass or auxiliary fuel. When the CHP system of an energy user meets the levels of effective thermal ratios and total thermal efficiencies set up by the MOEA, they may ask the local vertical integrated utilities (e.g., power companies) to purchase excess electricity at rational rates. This Act also stipulates that the energy conservation standards on the design and construction of new buildings should be promulgated by the competent authorities of building construction administration (i.e., Construction and Planning Agency under the Ministry of Interior, $\mathrm{CPA} / \mathrm{MOI})$ in conjunction with the MOEA.

\subsubsection{Ministry of Interior}

In order to achieve the goals of sustainable, comfortable, and healthy living environments, the central competent authority (i.e., MOI) promulgated the building technical regulations for promoting green buildings (GBs) and green building materials (GBMs) under the authorization of the Building Act [19]. The central competent authority of construction and implement (i.e., Architecture and Building Research Institute, ABRI) under the MOI established and launched the GBM Evaluation and Labeling System in the early 2000s. According to the definition of GBM by the ABRI, there are four categories of certified products, consisting of healthy GBMs, high-performance GBMs, recycled GBMs, and ecological GBMs. Among these categories, the use of wood and waste wood as building materials can be grouped into ecological GBMs and recycled GBMs, respectively. In order to further attain the achievable goals, Chapter 17 ("Green Building Guideline") was updated in the regulation ("Building Technical Rules-Building Design and Construction Compilation") on 18 August 2019. Effective from 1 January 2020, the minimum requirement for the application ratio of GBMs must be over $60 \%$ of total indoor surface area for interior decoration materials, floor materials, and windows, as well as over $20 \%$ of outdoor surface area for the ground materials.

\subsubsection{Council of Agriculture}

Forestry Act

The aim of the Act, which was recently revised in May 2021, was to preserve the forest resources, their natural functions, and their economic viability. The Council of Agriculture $(\mathrm{COA})$ is the central competent authority of forestry resource management. Under the Act, 
the carbon management with relevance to the wood resource utilization can be further summarized as follows:

- In order to increase the transfer of carbon from forest biomass to other wood products such as building materials and/or biomass fuels, harvesting of national forest yields shall be carried out according to the annual logging plan and national forest yield management code.

- Forestry enterprises may receive an award if they meet one of the relevant criteria, including large-scale cultivation of forests as a commodity to supply industry, national defense, ship building, road engineering, or other important applications, as well as those who invent or improve tree species, or who undertake bamboo and wood applications and crafts.

Organic Agriculture Promotion Act

On 30 May 2019, the Taiwan government began to promulgate the Organic Agriculture Promotion Act. One of the aims in the Act was to promote agricultural operation as a sustainable and eco-friendly use of resources without using chemical fertilizer, chemical pesticide, genetically modified organism (GMOs), and related products. In this regard, biochar is a valuable soil amendment for the benefits of both carbon sequestration and soil health, leading to its application in a variety of organic farming fields around the world [21]. The central competent authority (COA) is expected to promote agricultural production management systems which use natural resources in order to fulfill the eco-friendly requirement of organic agriculture. According to the Taiwan sustainable development goals [20], the organic agriculture promotion goal is set to 30,000 hectares (ha) in 2030, which is two times that in 2019. Therefore, the use of organic fertilizer in Taiwan has to increase significantly in the near future.

\subsection{Wood-Based Products for Mitigating the GHG Emissions \\ 3.3.1. Wood-to-Biochar}

Biochar is a carbonaceous product of biomass pyrolysis, which is operated at 300$800{ }^{\circ} \mathrm{C}$ in the absence or limited supply of oxygen. Therefore, biochar is derived from wood, bamboo, and other lignocellulosic materials. More significantly, biochar is considered an environment-friendly material because it can solidify the carbon from the biomass, thus delaying its release back to the atmosphere and making soils more fertile through the use of biochar as an organic fertilizer. In addition, biochar can be reused as a solid biofuel as it is rich in carbon (with a high calorific value) and low in sulfur [22]. When biochar sequesters more carbon (atmospheric $\mathrm{CO}_{2}$ ) than emitted, it is carbon-negative [21]. In summary, the motivations for applying biochar in a variety of fields include soil improvement (for improving soil fertility, as well as environmental quality), waste management (for alleviating environmental burden), climate change mitigation (for reducing GHG emissions), and energy production (for producing biomass fuel or bioenergy) [23].

In order to promote the use of biochar and mitigate the GHG emissions from the agricultural sector, the COA promulgated the regulation "Regulations Governing Certification of Good Agricultural Products" for certifying the quality and safety of agricultural products under the authorization of the Agricultural Production and Certification Act [19]. This regulation, recently revised on 30 October 2017, covers a variety of guidelines for good forestry products such as biochar (wood char, bamboo char), wooden products, laminated timber, and laminated bamboo. Furthermore, the Forestry Bureau was committed to building a certification for better awareness of domestic forest products among consumers. The forest product manufacturers which have already acquired the Traceable Agricultural Product (TAP) validation, the Forest Products Certification by CAS (Certified Agriculture Standards), and the QR Code of Taiwan Forest Products Production Traceability System can use the "Domestic Timber and Bamboo Certification Mark (the "Taiwan Wood" mark)" for their processed forest products. This system can encourage a gradual rise in market demand, drive the growth of wood/bamboo production and its industry 
chain, and provide a sustainable cycle of afforestation, utilization, and reforestation of artificial forests [24]. According to the Guidelines, the use of biochar covers a variety of applications, including fuel, moisture-conditioning, freshness-keeping, water treatment, deodorization, washing, healthcare, and fiber textile material activities. The test items of biochar products for performance quality depend on the application use, but they quantify moisture content, oven-dried fixed carbon, specific surface area, degree of refining, hardness, and calorific value. In line with Taiwan's sustainable development goals (SDGs) and the Organic Agriculture Promotion Act promulgated in 2019, the use of biochar in agricultural soils will gradually increase in the near future because the SDG for 2030 was set to 30,000 ha of organic farming area as compared to the organic farming area of about 14,000 ha in 2019 [21].

\subsubsection{Wood-to-Building Material}

According to the data on Taiwan's energy consumption in terms of various sectors in 2020 [25], the service and residential sectors accounted for about $15 \%$ of total domestic energy consumption. The percentage of service and residential sectors further shared about $35 \%$ of electricity consumption. These figures were counted in the subsector of heat and electricity (energy industries), as seen in Tables 1 and 2. Therefore, Taiwan's GHG emissions from the services and residential sectors in 2018 accounted for about $30 \%$ of total GHG emissions [18]. The GHG emissions from the service and residential sources indicated a decreasing trend from 9.5 million metric tons $\left(\mathrm{CO}_{2}\right.$ equivalent) in 2005 to 7.8 million metric tons in 2018. This can be attributed to the governmental policies for promoting energy saving, green energy (i.e., electricity/heat generation by renewable resources like solar energy), green buildings (GBs), and green building materials (GBMs) during this period $[26,27]$. In addition, the manufacturing and construction industries are responsible for a significant share of natural resources and energy consumption, thus emitting large amounts of GHGs, as listed in Tables 3 and 4.

In order to be in line with the trends of a low-carbon society and healthy indoor environment around the world, the Taiwan government has promulgated regulations for promoting GBMs under the authorization of the Building Act since the early 2000s [19]. Currently, there are four categories of GBM (ecology, health, high performance, and recyclability), which must be applied for approval by the central competent authority (i.e., MOI) [28]. According to the definition by the Building Technique Rules under the authorization of the Building Act, the constituents of GBMs are expected to meet regulatory requirements such as recycled wood products and natural materials. In this regard, the GBMs must be nontoxic to human health, nonhazardous to the environment, and in accordance with the national or international specifications/standards. Therefore, the evaluation items of GBMs include restricted substances, e.g., heavy metals and chlorinecontaining polymers [26,27]. Among the GBMs, the scope of wood-to-building material can be grouped into ecological GBMs and recycled GBMs, which are further summarized below.

\section{- Ecological GBMs}

An ecological GBM is defined as "a building material using natural materials with natural decomposition and without a shortage crisis, consuming minimal resources and energy, and requiring less labor treatment". Its goal is to promote the use of wooden building materials (including wooden building material, natural plant-based building material, wooden colorant, curtain, and wallpaper) for both environmental sustainability and human health. Therefore, the assessment focused on the certificates of Traceable Agricultural Products (TAP, described in Section 3.3.1), Forest Stewardship Council (FSC), Program for the Endorsement of Forest Certification Schemes (PEFC), or other certificates of origin. 


\section{- $\quad$ Recycled GBMs}

The goal of recycled GMB use is to reduce construction waste and reuse (or recycle) building materials such as wood ad minerals. Therefore, recycled GMBs focus on the regeneration of GBMs in order to ensure basic functional demand and the upgrade reuse (or recycling) rate of waste building material without causing secondary pollution or adverse effects on human health. The assessment items include the types of recycled building materials (e.g., particleboards, medium density fiber boards, and wooden furniture), their sources and recycled content percentage, and their test methods, which were based on the Taiwan's Chinese National Standards (CNS) standards and the International Organization for Standardization (ISO) standards.

In order to accelerate the development of GBMs, the ABRI, one of the public organizations under the central competent authority (i.e., MOI), has designated the architecture or design-related departments of national universities (e.g., National Cheng Kung University) and nonprofit organizations (e.g., Taiwan Architecture and Building Center) to assist the industry in evaluating the performance of the prepared building material products. According to the official statistics [28], the annual number of certified GBM labels from 2005 to 2020 indicated an increasing trend, reaching a total of 2668 certified GBM products. In 2020, a total of 292 GBM labels (including 199 new applications and 93 contract renewals) were issued, showing a significant increase of 38 from the previous year (2019). By the end of 2020, the percentages of certified GBM labels were $76.5 \%$ by health, $8.2 \%$ by recyclability, $14.9 \%$ by high-performance, and $0.4 \%$ by ecology. The distributions clearly reflected that wood-based GBM products are not currently preferred by manufacturers with the development trends of the GBM market in Taiwan.

\subsubsection{Wood-to-Energy}

According to the regulatory definition of biomass energy in the REDA, wood-to-energy refers to energy generated from the direct use or treatment of vegetation, marsh gas (biogas), and domestic organic waste. In this regard, waste wood can be considered an organic waste for reuse as an energy source. In Taiwan, waste is basically divided into "general waste" and "industrial waste" according to the Waste Management Act (WMA). Herein, the categories (or codes) of waste wood are considered industrial waste because they are generated from industrial activities such as manufacturing and construction industries. Waste wood can be grouped into D-type and R-type, depending on the reuse (or recycling) or treatment (incineration/disposal) costs. The factors affecting cost consideration involve reported amounts, waste wood constituents, and pretreatment requirements (e.g., shredding or physical/mechanical separation). As referred to in the database established by the EPA [29], Table 5 lists the reported amounts of waste wood in terms of categories during the period of 2010-2020. Obviously, the recycled amounts of R-type waste wood indicated an increasing trend, but the D-type waste wood showed a declining trend (D-07101 and D-0799). As shown in Figure 6, the variation in the reported amounts of waste wood suggested that the reuse (or recycling) has been prioritized by waste wood generators in recent years [29]. This situation can be attributed to the regulatory promotions and financial incentives for resource recycling, circular economy, wood-to-energy, or sustainable material management (SMM) since the early 2000s [30,31]. 
Table 5. Reported amounts of waste wood in terms of categories in Taiwan since $2010^{1}$.

\begin{tabular}{|c|c|c|c|c|c|c|c|c|c|c|c|}
\hline \multirow{2}{*}{ Waste Wood Category } & \multicolumn{11}{|c|}{ Year } \\
\hline & 2010 & 2011 & 2012 & 2013 & 2014 & 2015 & 2016 & 2017 & 2018 & 2019 & 2020 \\
\hline $\begin{array}{l}\text { Waste wood } \\
\quad(\mathrm{R}-0701)\end{array}$ & 52,191 & 45,494 & 58,184 & 64,639 & 56,331 & 53,783 & 52,012 & 60,728 & 67,121 & 65,197 & 71,855 \\
\hline $\begin{array}{l}\text { Waste wood pallet } \\
\text { (D-0701) }\end{array}$ & 3501 & 3782 & 3493 & 3587 & 3741 & 3807 & 3632 & 3537 & 2915 & 2238 & 2196 \\
\hline $\begin{array}{l}\text { Waste mixed wood } \\
\text { (D-0799) }\end{array}$ & 20,988 & 21,860 & 21,702 & 21,113 & 22,061 & 20,377 & 18,610 & 14,902 & 15,369 & 12,480 & 13,911 \\
\hline Total & 76,680 & 71,136 & 83,379 & 89,339 & 82,133 & 77,967 & 74,254 & 79,167 & 85,405 & 79,915 & 87,962 \\
\hline
\end{tabular}

${ }^{1}$ Source [29]; unit: metric tons.

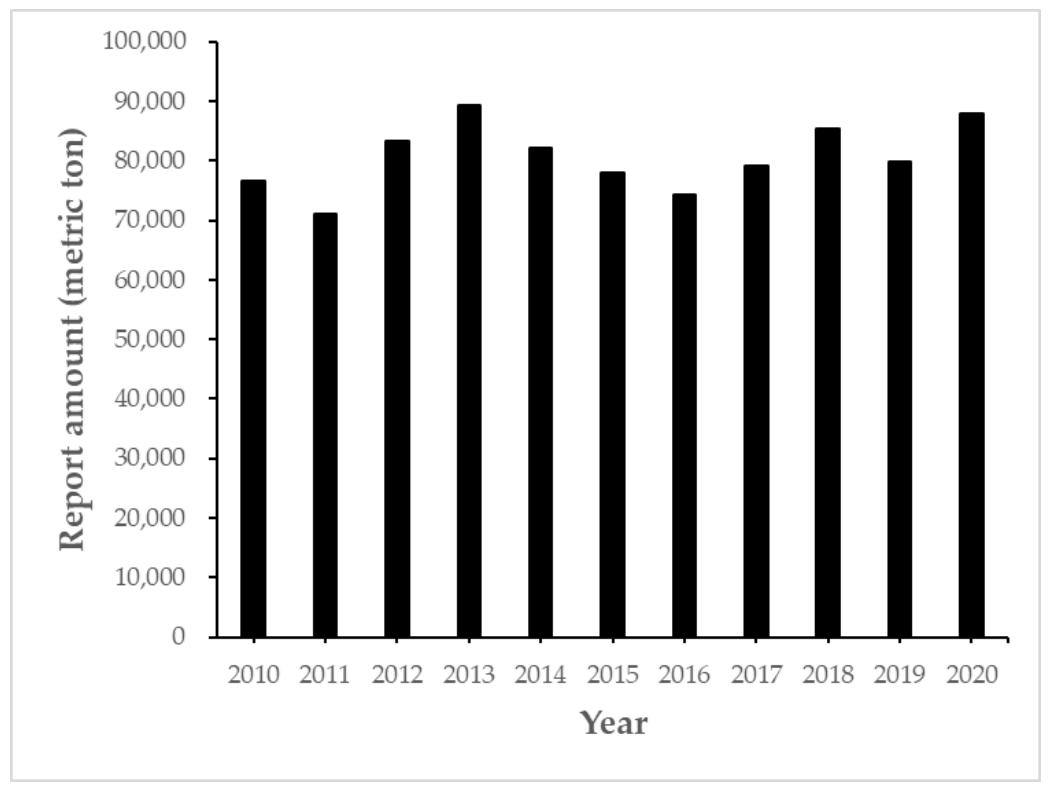

Figure 6. Variation in the reported amounts of waste wood in Taiwan during the period of 20102018 [29].

Over the past decades, waste-to-energy (WtE) has been confirmed as an environmentfriendly systems for exploiting the energy potential of high-carbon-containing wastes by means of the generation of electricity and/or heat [32]. In order to exploit the combustible fractions in the waste, the individual/mixed waste streams are subjected to pretreatment in mechanical separation plants. The solid recovered fuel (SRF) or produced secondary fuel has favorable economic (high calorific value), technical (small particle size, ash and moisture contents), and environmental (high biomass content) features. Therefore, SRF is increasingly used in a wide range of co-incineration plants such as high-efficiency boilers and combustion facilities [33]. In line with the international trends in the use of SRF, the Taiwan EPA formulated the Solid Recovered Fuel Manufacturing Guidelines and Quality Standards to ensure the manufacturing quality of SRF in 2020. Table 6 lists the quality standards of SRF in Taiwan, which are mainly based on the EN 15,359 standard ("Solid recovered fuels- Specifications and classes") [34]. On the other hand, the regulatory promotion for electricity generation from the WtE systems is based on the feed-in tariffs (FIT) under the authorization of the REDA. Figure 7 shows the FIT rates of biomass-toelectricity since 2010, indicating that a significant increase was seen in 2017 as compared to that in 2016. 
Table 6. Quality standards of solid recovered fuel (SRF) in Taiwan.

\begin{tabular}{ccccccc}
\hline Quality Item & Limit & & Unit & & Standard Method & Sample Basis \\
\hline Net calorific value & $\geq 2392$ & $\mathrm{kcal} / \mathrm{kg}$ & Average & CNS 10835 & As received $^{1}$ \\
\hline Clorine content & $\leq 3$ & $\%$ & Average & EN 15408 & $\mathrm{db}^{2}$ \\
\hline Mercury content & $\leq 5$ & $\mathrm{mg} / \mathrm{kg}(\mathrm{db})$ & Average & EN 15411 & As received $^{1}$ \\
\hline Lead content & $\leq 150$ & $\mathrm{mg} / \mathrm{kg}(\mathrm{db})$ & Average & EN 15411 & As received $^{1}$ \\
\hline Cadmiun content & $\leq 5$ & $\mathrm{mg} / \mathrm{kg}(\mathrm{db})$ & Average & EN 15411 & As received $^{1}$ \\
\hline
\end{tabular}

${ }^{1}$ Using wind-dried sample or moisture-constant sample. ${ }^{2}$ Dry basis.

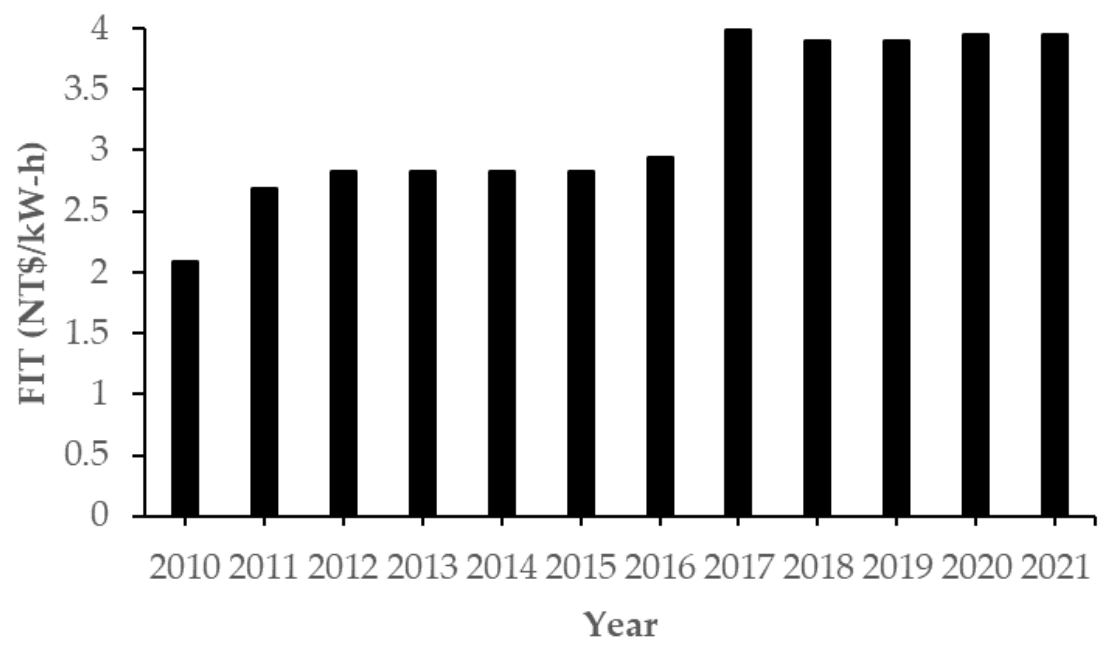

Figure 7. Feed-in tariff (FIT) rates of biomass-to-electricity in Taiwan since 2010.

\section{Conclusions}

Since the Kyoto Protocol was made effective in 2007, the decoupling of economic development from GHG emissions has become a core mission in governance. Although Taiwan is not a UNFCCC party, it has long been committed to fulfilling its responsibility as a member of the global community by endeavoring to take initiatives to help mitigate GHG emissions. An increase of $14.3 \%$ in the GHG emissions from the energy industries was obtained at an average annual growth rate of 1.68\% during the period of 2010-2018. More significantly, the GHG emissions from the manufacturing and construction industries indicated a decreasing trend at an average annual rate of $-2.93 \%$. In order to further reduce GHG emissions from the energy and agricultural sectors, the Taiwan government promulgated some regulatory measures and promotional actions (or programs) related to green energy production and efficient energy saving. One of the carbon-negative policies was to reuse waste wood as material and energy resources, including woodbased char, ecological building material, and wood-to-biofuel (e.g., solid recovered fuel) pathways. In line with the sustainable development goals (SDGs) of Taiwan, carbonnegative policies involving the reuse of waste wood and other lignocelluloses as material and energy resources will play an important role in the mitigation of GHG emissions by 2030. On the other hand, the forestry sector in Taiwan must provide more wood resources in wood-based products, which are important carbon substitution patterns.

Author Contributions: Conceptualization, W.-T.T.; data collection, W.-T.T.; data analysis, W.-T.T.; writing—original draft preparation, W.-T.T.; writing—review and editing, W.-T.T. The author have read and agreed to the published version of the manuscript.

Funding: This research received no external funding.

Institutional Review Board Statement: Not applicable. 
Informed Consent Statement: Not applicable.

Data Availability Statement: Not applicable.

Conflicts of Interest: The author declares no conflict of interest.

\section{References}

1. Food and Agricultural Organization, FAO. Carbon Storage and Climate Change Mitigation Potential of Harvested Wood Products. Available online: http:/ / www.fao.org/forestry/49800-0812a13ea85265539335c760f45630d3d.pdf (accessed on 5 August 2021).

2. Januszewicz, K.; Kazimierski, P.; Klein, M.; Kardaś, D.; Łuczak, J. Activated carbon produced by pyrolysis of waste wood and straw for potential wastewater adsorption. Materials 2020, 13, 2047. [CrossRef] [PubMed]

3. Kosakowski, W.; Bryszewska, M.A.; Dziugan, P. Biochars from post-production biomass and waste from wood management: Analysis of carbonization products. Materials 2020, 13, 4971. [CrossRef] [PubMed]

4. Haryanto, A.; Hidayat, W.; Hasanudin, U.; Iryani, D.A.; Kim, S.; Lee, S.; Yoo, J. Valorization of Indonesian wood wastes through pyrolysis: A review. Energies 2021, 14, 1407. [CrossRef]

5. Rodriguez-Franco, C.; Page-Dumroese, D.S. Woody biochar potential for abandoned mine land restoration in the US: A review. Biochar 2021, 3, 7-22. [CrossRef]

6. Bergman, R.; Puettmann, M.E.; Taylor, A.; Skog, K.E. The carbon impacts of wood products. For. Prod. J. 2014, 64, $220-231$. [CrossRef]

7. European Parliamentary Research Service. Biomass for Electricity and Heating: Opportunities and Challenges. 2015. Available online: https:/ / www.europarl.europa.eu/RegData/etudes/BRIE/2015/568329/EPRS_BRI(2015)568329_EN.PDF (accessed on 5 September 2021).

8. Brack, D. Sustainable Consumption and Production of Forest Products. In Proceedings of the Thirteenth Session of the United Nations Forum on Forests, New York, NY, USA, 7-11 May 2018; Available online: https:/ / www.un.org/esa/forests/wp-content/ uploads/2018/04/UNFF13_BkgdStudy_ForestsSCP.PDF (accessed on 5 September 2021).

9. Besserer, A.; Troilo, S.; Girods, P.; Rogaume, Y.; Brosse, N. Cascading recycling of wood waste: A review. Polymers 2021, 13, 1752. [CrossRef]

10. World Resources Institute, WRI. 4 Charts Explain Greenhouse Gas Emissions by Countries and Sectors. Available online: https:/ / www.wri.org/insights / 4-charts-explain-greenhouse-gas-emissions-countries-and-sectors (accessed on 5 August 2021).

11. Intergovernmental Panel on Climate Change (IPCC). 2006 IPCC Guidelines for National Greenhouse Gas Inventories; IPCC: Geneva, Switzerland, 2007.

12. Tsai, W.T.; Lin, Y.Q. Trend analysis of air quality index (AQI) and greenhouse gas (GHG) emissions in Taiwan and their regulatory countermeasures. Environments 2021, 8, 29. [CrossRef]

13. Chen, L.C.; Lin, J.C.; Wu, C.S.; Huang, G.M.; Chen, Y.H. The current status of the wood product in Taiwan. Q. J. Forest Res. 2012, 34, 287-296. (In Chinese)

14. Taiwan Forestry Research Institute, Council of Agriculture. Taiwan Forestry Knowledge Planform-Forestry Information. Available online: https:/ / woodsearch.tfri.gov.tw/information_statistics_search.php (accessed on 5 September 2021).

15. Sanchez, D.; Kammen, D. A commercialization strategy for carbon-negative energy. Nat. Energy 2016, 1, 15002. [CrossRef]

16. Goswami, M.; Pant, G.; Mansotra, D.K.; Sharma, S.; Joshi, P.C. Biochar: A carbon negative technology for combating climate change. In Advances in Carbon Capture and Utilization; Pant, D., Nadda, A.K., Pant, K.K., Agarwal, A.K., Eds.; Springer Nature: Singapore, 2021; pp. 251-272.

17. Vinci, G.; Ruggieri, R.; Billi, A.; Pagnozzi, C.; Di Loreto, M.V.; Ruggeri, M. Sustainable management of organic waste and recycling for bioplastics: A LCA approach for the Italian case study. Sustainability 2021, 13, 6385. [CrossRef]

18. Environmental Protection Administration (EPA). Taiwan Greenhouse Gases Inventory; EPA: Taipei, Taiwan, 2020.

19. Ministry of Justice, Taiwan. Laws and Regulation Retrieving System. Available online: https://law.moj.gov.tw/Eng/index.aspx (accessed on 3 August 2021).

20. Council for Sustainable Development. Annual Review Report on the Taiwan's Sustainable Development Goals; Environmental Protection Administration: Taipei, Taiwan, 2020. (In Chinese)

21. Das, S.K.; Avasthe, R.K.; Singh, R.; Babu, S. Biochar as carbon negative in carbon credit under changing climate. Curr. Sci. 2014, 107, 1090-1091.

22. Basu, P. Biomass Gasification, Pyrolysis and Torrefaction: Practical Design and Theory, 2nd ed.; Academic Press: San Diego, CA, USA, 2013; pp. 47-86.

23. Lehmann, J.; Joseph, S. Biochar for environmental management: An introduction. In Biochar for Environmental Management, 2nd ed.; Lehmann, J., Joseph, S., Eds.; Routledge: New York, NY, USA, 2015; pp. 1-13.

24. Tsai, W.T. Forest resource management and its climate-change mitigation policies in Taiwan. Climate 2021, 9, 3. [CrossRef]

25. Ministry of Economic Affairs (MOEA). Energy Statistics Handbook; MOEA: Taipei, Taiwan, 2021.

26. Hsieh, T.T.; Chiang, C.M.; Ho, M.C.; Lai, K.P. The application of green building materials to sustainable building for environmental protection in Taiwan. Adv. Mater. Res. 2012, 343, 267-272. [CrossRef]

27. Tsai, W.T. Overview of green building material (GBM) policies and guidelines with relevance to indoor air quality management in Taiwan. Environments 2018, 5, 4. [CrossRef] 
28. Taiwan Architecture and Building Center, TABC. Green Building Materials. Available online: https://www.tabc.org.tw/tw/ modules/about/gbm (accessed on 13 June 2021).

29. EPA, Taiwan. Industrial Waste Reporting and Management Information System. Available online: https:/ / waste.epa.gov.tw / RWD/Statistics/?page=Month1 (accessed on 16 July 2021).

30. Tsai, W.T.; Chou, Y.H. Overview of environmental impacts, prospects and policies for renewable energy in Taiwan. Renew. Sustain. Energy Rev. 2005, 9, 119-147. [CrossRef]

31. Tzou, L.; Liu, K.H.; Hu, A.H. The development of sustainable materials management (SMM) and circular economy in Taiwan. In Waste Management and Resource Efficiency; Ghosh, S., Ed.; Springer: Singapore, 2019; pp. 209-217.

32. Makarichi, L.; Jutidamrongphan, W.; Techato, K. The evolution of waste-to-energy incineration: A review. Renew. Sustain. Energy Rev. 2018, 91, 812-821. [CrossRef]

33. Lorber, K.E.; Sarc, R.; Aldrian, A. Design and quality assurance of solid recovered fuel. Waste Manag. Res. 2012, 30, 370-380. [CrossRef] [PubMed]

34. Flamme, S.; Geiping, J. Quality standards and requirements for solid recovered fuels: A review. Waste Manag. Res. 2012, 30, 335-353. [CrossRef] [PubMed] 